\title{
Deficiency of the Interleukin-36 Receptor Antagonist
}

National Cancer Institute

\section{Source}

National Cancer Institute. Deficiency of the Interleukin-36 Receptor Antagonist. NCI

Thesaurus. Code C119057.

An autoinflammatory disease caused by mutations in the IL36RN gene, which encodes

the IL36 receptor antagonist. It is characterized by periodic fevers and psoriasiform rash. 